\title{
Correction to: The 30 October 2020 Aegean Sea Tsunami: Post-Event Field Survey Along Turkish Coast
}

\author{
Gozde Guney Dogan, ${ }^{1}$ (D) Ahmet Cevdet Yalciner, ${ }^{1}$ Yalcin Yuksel, ${ }^{2}$ Ergin Ulutaş, ${ }^{3}$ Orhan Polat, ${ }^{4}$ \\ Iş1Khan GÜler, ${ }^{1}$ Cihan ŞAhin, ${ }^{2}$ Ahmet Tarih, ${ }^{5}$ and UtKu KÂNoĞLU ${ }^{6}$
}

Correction to: Pure Appl. Geophys. 178 (2021), 785-812 https://doi.org/10.1007/s00024-021-02693-3

In the original version of this paper two of the cited references were inadvertently not listed in the literature list.

The missing references in the literature list should read:

Triantafyllou, I., Gogou, M., Mavroulis, S., Lekkas, E., Papadopoulos, G.A., Thravalos, M. (2021). The Tsunami Caused by the 30 October 2020 Samos (Aegean Sea) Mw7.0 Earthquake: Hydrodynamic
Features, Source Properties and Impact Assessment from Post-Event Field Survey and Video Records. Journal of Marine Science and Engineering, 9(1), 68. https://doi.org/10.3390/jmse9010068.

Arikawa, T., Guler, H. G., \& Yalciner, A. C. (2017). Comparison of human response against earthquake and tsunami. In American Geophysical Union Fall Meeting, December 11-15, 2017, New Orleans, USA. Abstract \#NH12A-05. https://agu. confex.com/agu/fm17/meetingapp.cgi/Paper/300513

The original article has been corrected. We apologise for any inconvenience caused to our readers.

The original article can be found online at https://doi.org/10.1007/ s00024-021-02693-3.

\footnotetext{
1 Ocean Engineering Research Center, Department of Civil Engineering, Middle East Technical University, Ankara, Turkey. E-mail: gguneydogan@gmail.com

2 Hydraulics Division, Department of Civil Engineering, Y1ldız Technical University, İstanbul, Turkey.

3 Seismology Division, Department of Geophysics Engineering, Kocaeli University, Kocaeli, Turkey.

4 Seismology Division, Department of Geophysics Engineering, Dokuz Eylül University, İzmir, Turkey.

5 Directorate of Earthquake and Ground Research, İstanbul Metropolitan Municipality, İstanbul, Turkey.

6 Department of Engineering Sciences, Middle East Technical University, Ankara, Turkey.
} 